\title{
Lumbering Activities and Market Equilibrium Analysis of Timber Industry in South Western Nigeria
}

\author{
Akanni K. A. ${ }^{1}$ \\ ${ }^{1}$ Department of Agricultural Economics, College of Agricultural Sciences, Olabisi Onabanjo University, \\ Ago-Iwoye, Ogun State, Nigeria \\ Correspondence: Akanni K. A, Department of Agricultural Economics, College of Agricultural Sciences, Olabisi \\ Onabanjo University, Ago-Iwoye, Ogun State, Nigeria. Tel: 234-805-604-6858. E-mail: \\ akannikunle2003@yahoo.co.uk
}

Received: June 26, 2012 Accepted: August 8, 2012 Online Published: October 10, 2012

doi:10.5539/sar.v2n1p44 URL: http://dx.doi.org/10.5539/ sar.v2n1p44

\begin{abstract}
The local lumbers, without restraints, are continually exploiting the Nigerian forests. This trend causes a massive reduction in the economic, recreational, water purification and other benefits derivable from the forest and forest products. The overall implication of this is that there is a shortfall in the market supply of wood and wood products in South Western Nigeria. This situation poses some challenges to the government, private operators and other stakeholders in timber industry. This study therefore, investigated the implications of the activities of the lumbers and the market equilibrium structure of wood industry in the region. Both the stochastic production frontier and market equilibrium analyses were done. Fuel, credit and trucks' carrying capacities significantly determined the quantity of output of the lumbers. The estimates of the sigma square, $\delta^{2}(0.3811)$ and gamma, $\gamma$, (0.9001) were positively significant at $1 \%$ level. The log likelihood function was large (24.6672) indicating a good fit. Estimated demand elasticity indicated that N1.00 increase in market price produced $14.14 \%, 52.73 \%$ and $55.12 \%$ decrease in the quantities demanded for $2 \times 3 \times 12,3 \times 4 \times 12$ and $2 \times 6 \times 12$ wood sizes. To further increase the output level of wood products in the region therefore, it is necessary to stabilize fuel prices and make the product available to the lumbers at the required time and quantities.
\end{abstract}

Keywords: local lumbers, market supply of wood and wood products, market price, elasticity values, south western Nigeria

\section{Introduction}

By virtue of its location in the tropical rainforest zone (in the south) and savannah grassland (in the north), Nigeria is largely endowed with huge forest and wood resources. The forest industry consists of both the informal and formal sectors while the forest products include fuelwood, charcoal, round wood, sawn woods, wood- based panels, pulp and paper. The nature of statistics on these products is disjointed because there are no systematized methodologies for their regular collection either at the Federal, State or at the local government levels. The major wood processing industries in Nigeria are typically big capacity facilities such as large sawmills, ply wood mills, pulp and paper plants etc. In particular, the sawmills are designed to handle large diameter logs and are essentially distributed between small, medium and large scale in the proportion of $81 \%$, $13 \%$ and $6 \%$ (FDF, 1984). Though the number of sawmills is on the decrease, production has not decreased commensurately. This is because even though wood industries find it difficult to obtain desirable sizes of popular tree species like Mansonia Ultissima, Milicia exclesa and Khaya species from the Nigerian forest, they have been forced to expand the range of exploited species, which hitherto were regarded as uneconomic. Such species include celtic zinkarri, cola acuminata,ceiba pentandra, chrsytophylum albidum etc. In the past, Nigeria was endowed with abundant timber resources, which are well spread throughout the geographical land area. Today, due to excessive exploitation and indiscriminate logging activities, less than $10 \%$ of the nation's land area is under high forest cover (Adekunle, 2005; Adepoju \& Salau, 2007; Aiyeloja \& Ajewole, 2006; Andel, 2006). While corroborating this position, Ajakaiye (2001), Athanius (2005) and Awe et al. (2011) added that the area of land per capita has reduced drastically from about 350 hectares in 1960 to about 90 hectares in 1999. Quite often, many local lumbers see the forests as open assets resources for easy exploitation without any recourse to constituted authorities. Illegal and indiscriminate tree felling activities of these lumbers are more pronounced in 
the 'free areas', which are considered to be beyond the control of the forest guards and officials. This is in agreement with Hardin (1968) who, while writing on the "Tragedy of the Commons" noted that all resources held in common will inevitably suffer over-exploitation and degradation. The overall implication of this is that there is a shortfall in the market supply of wood and wood products in South Western Nigeria.

Most often, irreparable damages are inflicted on many parts of the forests ecosystem during mechanical and manual timber harvesting. The total forest area is affected by crawler tractors, felling damage and during road and gantry construction. Ola-Adams (1983) reported that about $17.74 \%$ residual trees suffered logging damages and about $8 \%$ of the virgin ground is left bare and damaged. This intensive exploitation of the forest has led to the loss of biodiversity and extinction especially of many tropical plant species with narrow range. At the present rate of exploitation, Adekunle (2005) reported that many Nigerian plant species, especially the rare and endemic ones, are in serious danger. Animals are also killed during felling and logging activities and the destruction of their habitat produces immediate changes in the number of available wildlife.

However, in South Western Nigeria, the common tree varieties, according to FDF (1984), include Apa (afezelia africana), opepe (nauclea diderrichi), afara (terminalia superba), iroko (milicia excelesa) and ita (lophira alata) among others. These resources are available both on government reserves and in 'free areas'. Indiscriminate felling of trees has endless damaging effects on the environment, locality and the global space. Thus, there is a continuous reduction in the economic, recreational, water purification and other benefits derivable from the presence of forest and forest products. The hitherto existing culture of selective cutting of only the mature timbers (silviculture) has given way for reckless mass cutting of trees and poles. Thus, our forests are losing their beauty, candour and vast economic potentials. This thus calls for a compelling attention from the government, private operators and the stakeholders in timber industry.

Even though there are several documented literature materials on forestry economics, those ones that dwell concisely on resource use and market equilibrium structure of the common wood products is uncommon in the study area. Thus, this study is quite distinct.

In this study therefore, the researcher investigated the implications of the activities of the lumbers on the market equilibrium of wood products in South Western Nigeria.

\section{Methods}

The study area for this research is South Western Nigeria, which is made up of six (6) states: Oyo, Ondo, Ogun, Osun, Ekiti and Lagos. It constitutes about $10.8 \%$ of the total countrywide land area of $924,000 \mathrm{~km}^{2}$ (Ojo \& Duze, 1977) and lies between latitude $4^{\circ} 15^{\prime} \mathrm{N}$ (Southern tip of the Niger Delta on the Atlantic) and $13^{\circ} 55^{\prime} \mathrm{N}$ (North Western frontier with Benin) and $14^{\circ} 40^{\prime} \mathrm{E}$ (North Eastern frontier with Cameroon). There are 36 states and the Federal Capital Territory of Abuja. According to the National Population Commission, NPC (2006), estimated 30 million people, or about $22 \%$ of Nigerians, reside in the region.

\subsection{Sources of Data and Sampling Technique}

The data used for this study were obtained from both the primary and secondary sources. Primary data were obtained through the use of sets of structured questionnaire and personal interview while secondary data were gathered from existing literature on the topic. Multi-stage sampling technique was used to collect the data. This involved the identification of forest zones in each state and then the towns/communities where lumbering activities are done. Finally, active lumbers were identified through the assistance of the saw milling industries. A total of fifty (50) lumbers and 6 sawmills were randomly selected from each of the six (6) states in the region, thus giving 300 lumbers and 36 sawmills for the study. Information was gathered on the total carrying capacities of the trucks, the spread and economic activities of the lumbers. Facts were also gathered on the market prices, demand and supply schedules for the various wood sizes at the sawmills.

\subsection{Method of Data Analysis}

Both the stochastic production frontier model and market equilibrium analyses were done. The estimated stochastic production frontier model, written explicitly, is as follows;

$$
* \operatorname{Ln} Q_{1 i j}=\beta o+\beta_{1} \ln X_{1}+\beta_{2} \ln X_{2}+\ldots \ldots . .+\beta_{7} \ln X_{7}+v_{i j} u_{i j}
$$

Where,

$\mathrm{Q}_{1 \mathrm{ij}=}$ Quantity of trees (hardwoods) fell per month (tonnes);

$\mathrm{X}_{1=}$ Quantity of labour used per lumber/month (hours)

$\mathrm{X}_{2}=$ Quantity of fuel used per lumber/month (litres) 
$\mathrm{X}_{3}=$ Credit base of lumber $(\mathrm{N})$

$\mathrm{X}_{4}=$ Number of sawing machines (Units)

$\mathrm{X}_{5}=$ Number of machetes (Units)

$\mathrm{X}_{6}=$ Number of axes (Units)

$\mathrm{X}_{7}=$ Trucks' carrying capacities (tonnes)

* Members of the public generally treat the Nigerian forests, particularly the free areas, as open access resources with unlimited lumbering activities. The stochastic frontier function therefore did not reflect 'seeding' i.e. 'addition of raw material inputs' since the lumbers only exploit/harvest the forest without any attempt at planting young seedlings (afforestation) in return.

$\mathrm{V}_{\mathrm{ij}}$ and $\mathrm{u}_{\mathrm{ij}}$ are the decomposed error terms $\left(\epsilon_{\mathrm{ij}}\right)$ which are stochastic in nature/behaviour (Aiger et al., 1977; Meeusen \& van den Broeck, 1977). They represent production errors/distortions due to technical and allocative inefficiencies respectively.

The two components, $\mathrm{v}_{\mathrm{ij}}$ and $\mathrm{u}_{\mathrm{ij}}$, are assumed to be independent of each other.Vij is the two-sided, normally distributed random error $\mathrm{V} \approx \mathrm{N}\left(\mathrm{o}, \delta^{2}\right)$ and $\mathrm{u}_{\mathrm{ij}}$ is the one-sided efficiency component with a half- normal distribution $\mathrm{U} \approx \mathrm{N}\left(\mathrm{o}, \delta^{2}\right)$.The maximum likelihood estimation of the expression of stochastic error term yields the estimation for $\beta$ and $\lambda$ where $\beta$ was defined as earlier, $\lambda=, \delta u / \delta v$ and $\delta^{2}=\delta u^{2}+\delta v^{2}$.

$\beta o$ is the constant term while $\beta_{1}-\beta_{7}$ are the parameters to be estimated. Ln is however, the natural logarithm. The a priori expectation is that all the independent variables $\left(\mathrm{X}_{1}-\mathrm{X}_{7}\right)$ should have a positive relationship with the quantity of trees that were felled per month.

The corresponding (dual) cost frontier model, written explicitly, is given as;

$$
\text { Ln C1ij }=\varphi 0+\varphi 1 \ln Q 1 \mathrm{ij}+\varphi 2 \ln \mathrm{C} 1+\ldots \ldots \ldots+\varphi 8 \ln \mathrm{C} 7+\text { vij- uij }
$$

Where,

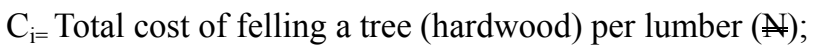

$\mathrm{Q}_{1 \mathrm{ij}=}$ Quantity of hardwood fell per lumber/month (tonnes)

$\mathrm{C}_{1}=$ wage rate/hour of labour $((\AA)$

$\mathrm{C}_{2}=$ Price per litre of fuel $((\$)$

$\mathrm{C}_{3}=$ cost of credit used (( $\left.\$\right)$

$\mathrm{C}_{4}=$ cost per unit of sawing machine $((\mathrm{N})$

$\mathrm{C}_{5}=$ cost per unit of machete $((\$)$

$\mathrm{X}_{6}=$ cost per unit of axe $((\mathrm{N})$

$\mathrm{X}_{7}=$ cost per unit of truck $((\mathrm{N})$

Note: Naira, (N) is the unit of Nigerian currency. Presently (July, 2012), $\$ 162.00$ is exchanged for USD1.00

$\mathrm{v}_{\mathrm{ij}}$ and $\mathrm{u}_{\mathrm{ij}}$ are as earlier defined

$\varphi \mathrm{o}=$ constant term

$\varphi_{1}-\varphi_{8}=$ parameters to be estimated

The a priori expectation is that all the independent variables $\left(\mathrm{C}_{1-} \mathrm{C}_{7}\right)$ should have a positive relationship with the total cost of felling one (1) tonne of hardwood. The estimated Stochastic function is the basis for deriving a stochastic cost frontier and the related efficiency measures (Bravo Ureta \& Rieger, 1991). This is because the stochastic production function is self-dual. This functional form, according to Battese and Coelli (1988), Bravo-Ureta and Pinheiro (1993) had been widely used in farm efficiency analysis for both developing and developed countries. The stochastic production function was therefore fit into the lumbering activities in the region, using maximum likelihood procedures. The market schedule analysis was also used to examine the supply and demand structure of wood to the markets by the sawmills. Generally, market prices are determined by the interaction of forces of demand and supply (Stonier \& Hague, 1972). The market schedule for wood was therefore estimated by obtaining varying market supply and the demand for wood and their corresponding prices. Thus, the elasticity of demand and supply was estimated as;

i) Elasticity of Demand $\mathrm{Ed}=\partial \mathrm{Q} / \mathrm{Q} * \mathrm{P} / \partial \mathrm{P}$ 
where,

$\partial \mathrm{Q}=$ Change in quantity of woods demanded (Units)

$\mathrm{Q}=$ Quantity of wood demanded (Units)

$\mathrm{P}=$ Price per unit of demanded woods (( $)$

$\partial \mathrm{P}=$ Change in Price $((\mathrm{N})$

ii) Elasticity of supply, Es $=\partial \mathrm{S} / \mathrm{S} * \mathrm{P} / \partial \mathrm{P}$

Where,

$\partial \mathrm{Q}=$ Change in quantity supplied (tonnes)

$\mathrm{S}=$ Quantity supplied (Tonnes)

$\mathrm{P}=$ Price per unit of supplied woods $((\mathrm{N}) ; \partial \mathrm{P}=$ Change in Price $((\mathrm{N})$

\section{Results}

\subsection{Estimation of the Determinants of Production Output Levels of Wood Products in Southwestern Nigeria}

Maximum likelihood estimate (MLE) of stochastic production frontier, using frontier package (version 4.1) is as given on Table 1. Only three (3) of the independent variables were significant: fuel (5\% level); credit facilities and trucks capacity $\left(1 \%\right.$ level). The estimates of the sigma square $\delta s^{2},(0.3811)$ and gamma, $\gamma,(0.9001)$ are positively significant at $1 \%$ level, while the log likelihood function maintained a fairly large value (24.6672).

The estimated stochastic production frontier (MLE), is given as;

$$
\begin{aligned}
& \mathrm{LnQ} 1 \mathrm{ij}=1.012+0.3462 \ln \mathrm{X} 1+1.9376 \ln \mathrm{X} 2+1.8943 \ln \mathrm{X} 3+2.4848 \ln \mathrm{X} 4+0.3261 \ln \mathrm{X} 5+0.2846 \ln \mathrm{X} 6+3.3162 \ln \mathrm{X} 7 \text { (3) } \\
& \begin{array}{lllllll}
(0.9341) & (1.0031) & (2.5046) & (4.0383) & (0.9334) & (0.6388) & (1.1141)
\end{array}
\end{aligned}
$$

Table 1. Parameter estimates of the determinants of production levels in wood industry (300)

\begin{tabular}{lll}
\hline Variabe & Estimated Parameter $\left(\beta_{\mathrm{i}}\right)$ & $\mathrm{t}$-value \\
\hline Constant & 1.012 & 0.9341 \\
Labour $\left(\mathrm{X}_{1}\right)$ & 0.3462 & 1.0031 \\
Fuel $\left(\mathrm{X}_{2}\right)$ & $1.9376^{* *}$ & 2.5046 \\
Credit $\left(\mathrm{X}_{3}\right)$ & $1.8943^{* * *}$ & 4.0383 \\
Sawing Machine $\left(\mathrm{X}_{4}\right)$ & 2.4848 & 0.9334 \\
Machetes $\left(\mathrm{X}_{5}\right)$ & 0.3261 & 0.6388 \\
Axes $\left(\mathrm{X}_{6}\right)$ & 0.2846 & 1.1141 \\
Trucks carrying capacities $\left(\mathrm{X}_{7}\right)$ & $3.3162^{* * *}$ & 2.8894 \\
Lambda, $\lambda$ & $2.1311^{* * *}$ & 3.0003 \\
Gamma $(\gamma)$ & $0.9001^{* * *}$ & 17.1471 \\
$\delta \mathrm{s}^{2}=\delta \mathrm{u}^{2}+\delta \mathrm{v}^{2}$ & $0.3811^{* * *}$ & 3.6943 \\
Log likelihood function & 24.6672 & \\
\hline
\end{tabular}

Source: Computed from survey data, 2010.

Note: Figures in parentheses are standard errors.

**=Significant @ $5 \%$ level.

***=Significant @1\% level.

From Table 2 below, it is shown that for $2 \times 3 \times 12$ wood size, estimated quarterly average of 253,500 tonnes and 256,000 tonnes of processed woods were demanded and supplied respectively. 
Table 2. Estimated market schedules for $2 \times 3 \times 12$ wood size (Number of Sawmills $=36$ )

\begin{tabular}{lllllll}
\hline Quarter & $1^{\text {st }}$ & $2^{\text {nd }}$ & $3^{\text {rd }}$ & $4^{\text {th }}$ & Total & Average \\
\hline Price/Unit (N) & 740 & 860 & 980 & 1,120 & 3,700 & 925.0 \\
Quantity demanded ( tons) & 262,000 & 258,000 & 251,000 & 243,000 & $1,014,000$ & 253,500 \\
Quantity supplied (tons) & 236,000 & 248,000 & 265,000 & 275,000 & $1,024,000$ & 256,000 \\
\hline
\end{tabular}

Table 3. Estimated market schedules for $3 \times 4 \times 12$ wood size (Number of Sawmills $=36$ )

\begin{tabular}{lllllll}
\hline Quarter & $1^{\text {st }}$ & $2^{\text {nd }}$ & $3^{\text {rd }}$ & $4^{\text {th }}$ & Total & Average \\
\hline Price/Unit (N) & 880 & 930 & 1050 & 1200 & 1,810 & 1,015 \\
Quantity demanded (tons) & 334,000 & 326,800 & 298,000 & 279,050 & $1,237,850$ & $309,462.50$ \\
Quantity supplied (tons) & 300,000 & 318,800 & 348,000 & 362,000 & $1,328,800$ & 332,200 \\
\hline
\end{tabular}

Table 4. Estimated market schedules for $2 \times 6 \times 12$ wood size (Number of Sawmills=36)

\begin{tabular}{lllllll}
\hline Quarter & $1^{\text {st }}$ & $2^{\text {nd }}$ & $3^{\text {rd }}$ & $4^{\text {th }}$ & Total & Average \\
\hline Price/Unit (N) & 520 & 550 & 630 & 830 & 2,530 & 632.50 \\
Quantity demanded (tons) & 280,000 & 226,000 & 193,600 & 188,000 & 887,600 & 221,900 \\
Quantity supplied (tons) & 216,000 & 224,800 & 240,000 & 256,000 & 936,800 & 234,200 \\
\hline
\end{tabular}

Source: Survey data, 2010

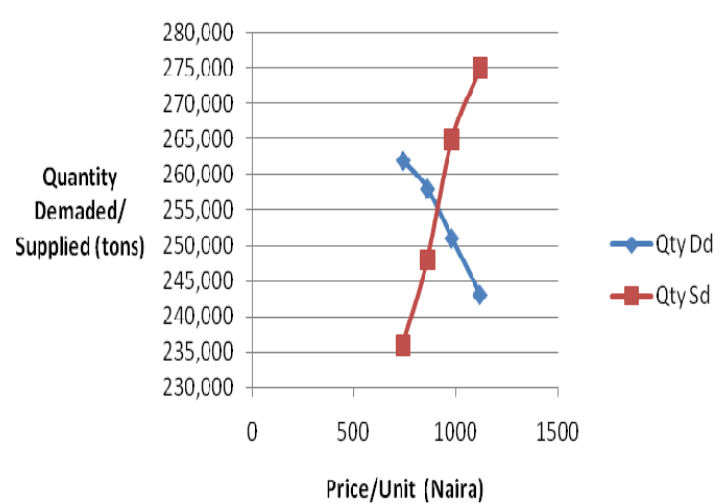

Figure 1. Market schedule ( $2 \times 3 \times 12$ wood size $)$

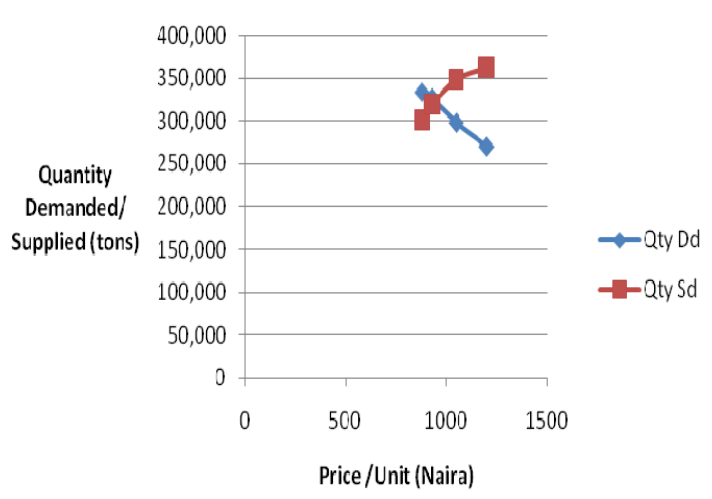

Figure 2. Market schedule ( $3 \times 4 \times 12$ wood size $)$

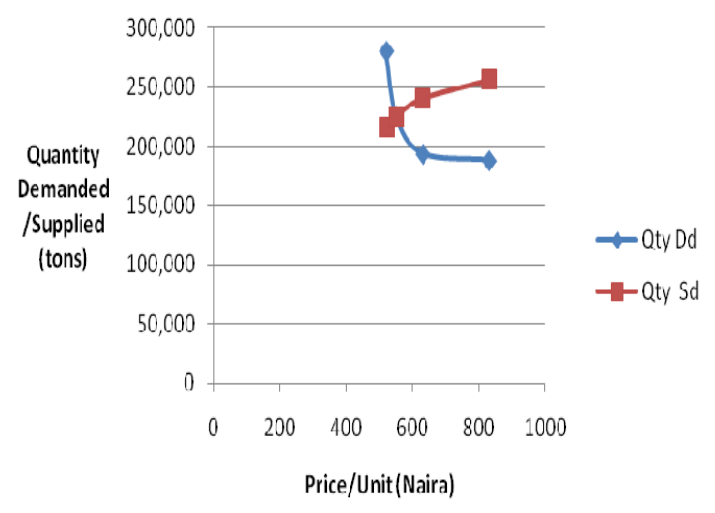

Figure 3. Market schedule ( $2 \times 6 \times 12$ wood size $)$ 
In Table 5, the estimates of the elasticity of the market demand for and supply of wood products were given.

Table 5. Estimation of annual elasticity of demand and supply (Number of Sawmills=36)

\begin{tabular}{lcc}
\hline Wood size & Elasticity of Supply & Elasticity of Demand \\
\hline $2 \times 3 \times 12$ & -0.3221 & 0.1414 \\
$3 \times 4 \times 12$ & -0.5684 & 0.5273 \\
$2 \times 6 \times 12$ & -0.3112 & 0.5512 \\
\hline
\end{tabular}

Source: Survey data, 2010.

\section{Discussion}

The estimate of lambda, $\lambda(2.1311)$ was large and significantly different from zero at $1 \%$ level. This, according to Pindyck and Rubinfeld (1998), indicates a good fit. It was also observed that the signs preceding all the variables agreed with the a priori expectations. Quantitatively, about 2.0, 1.9, 2.5, and 3.3 units of fuel, credit, sawing machines and trucks' carrying capacities were capable of producing 1 unit increase in the quantity of woods produced by the lumbers respectively. However, estimated 0.3 unit of labour, machetes and axes was capable of causing 1 unit increase in the level of wood output.

As a policy measure therefore, all the three significant variables must be treated with the required level of seriousness to ensure an increased wood production level. Fuel prices need to be stabilized and the commodity should be available at the required time and quantities. Credit facilities need to be adequately supplied and the trucks' carrying capacities need to be increased. As a way out therefore, the lumbers may be encouraged to join co-operative societies, because they provide less stringent conditions for granting loans to members. The rural roads also need repairs and many more need to be constructed so as to enable the trucks perform at full capacity levels.

The total quantities of woods that were demanded and supplied stood at 1,014,000 tonnes and 1,024,000 tonnes respectively. The average unit price of the product was 925.00 per year while the average aggregate demand for and the supply of the product stood at 253,500 tonnes and 256,000 tonnes respectively. In Table 3 however, a total of $1,237,850$ tonnes and $1,328,800$ tonnes of $3 \times 4 \times 12$ wood size were demanded for and supplied respectively. Estimated total average of 309,462.5 tonnes and 332,200 tonnes of processed woods were demanded and supplied per quarter respectively while the yearly average for the product was $\mathbb{N} 1,015.00$. In Table 4, 936,800 tonnes and 887,600 tonnes were supplied and demanded in the wood markets. Estimated quarterly average of 221,900 tonnes and 234,200 tonnes of processed woods were demanded and supplied in the markets with yearly average market price of $\$ 632.50$. Graphical illustrations were presented in Figures 1-3. It should however be noted that, generally, the market supply of planks had been augmented by the addition of various wood types that were hitherto considered uneconomic (FDF, 2002; Sale, 2006; Olumide, 2009). Values of demand elasticity were $0.1414,0.5273$, and 0.5512 for $2 \times 3 \times 12,3 \times 4 \times 12$ and $2 \times 6 \times 12$ wood sizes respectively. The implication of this is that N1.00 increase in the market price of the products produced $14.14 \%$, $52.73 \%$ and $55.12 \%$ decrease in the quantity demanded of the respective wood sizes. Similarly, estimated values of supply elasticity were $-0.3221,-0.5684$ and -0.3112 for $2 \times 3 \times 12,3 \times 4 \times 12$ and $2 \times 6 \times 12$ respectively. This indicates that $\mathrm{N} 1.00$ drop in price brought about $32.21 \%, 56.84 \%$ and $31.12 \%$ decline in the quantity of wood supplied respectively.

The supply response to changing market prices was highest (56.84\%) for $3 \times 4 \times 12$ wood size. This is about double the supply response in respect of other wood sizes (Table 5). From the above, it is inferred that there is a fairly stable market price for wood products in the region and that the wood market operators are very sensitive to varying (marginal) market situations. Wood sellers are however more responsive to changing market prices, thus confirming that the wood products market in the region is highly demand-elastic (Adekunle, 2005; Adetula, 2002). The aggregate supply levels of the wood products generally overshoot their demand. This was made possible because wood industries have been forced to expand and utilize the range of exploited tree species, which hitherto were regarded as uneconomic. Such species include celtic zinkarri, cola acuminata,ceiba pentandra, chrsytophylum albidum etc. This position is supported by Sale (2006) and Olumide (2009).

\section{Conclusion}

Despite the richness of the Nigerian forests in terms of fuel wood, charcoal, round wood etc, there is still a huge 
shortfall in the market supply of the products.

This has been largely attributed to the problems of excessive exploitation and indiscriminate logging activities, which have left less than $10 \%$ of the nation's land area under high forest cover (Adekunle, 2005; Aiyeloja \& Ajewole, 2006; Adepoju \& Salau, 2007). The study, therefore investigated the determinants of production levels and the market equilibrium structure of certain products in wood industry in South Western Nigeria. Fuel, credit and trucks capacity were significant independent variables at $1 \%$ and $5 \%$ levels. Estimated values of the sigma square $\left(\delta \mathrm{s}^{2}\right),(0.3811)$ and gamma $(\lambda),(0.9001)$ and log likelihood function (24.6672) indicated that the model was of good fit. The market analysis showed that the demand for wood products is price- elastic throughout the year. This implies that fluctuation in the prices of the wood products may negatively affect the possibility of a precision budgeting in construction industry where these wood products are largely consumed. As a way out therefore, government forest reserves could be re-invigorated to continue to complement timber supplies from the existing 'free areas'. This will eventually force down the market price levels of the commodities.

As a policy measure to further increase the output level of wood products therefore, fuel prices need to be stabilized and the product made available to the lumbers at the required time and quantities. Credit facilities also need to be adequately supplied in the right measures and time while the roads in the jungles where most of the forest resources are available need to be made pliable for the trucks. More roads need to be constructed in the open forests and the government reserves so as to ensure a better road distribution network. With this, they (the trucks) will be able to perform to full capacity levels and thus help to further increase the market supply level of the commodities.

Finally, strict but environment- friendly policy measures should be put in place by government to protect the forests from the abuse and indiscriminate tree felling while offenders are made to face stiff penalties. This is in line with the earlier positions of Adetula (2002), Ajakaiye (2001), Aiyeloja and Ajewole (2006), Awe et al (2011) while writing on the roadmap for a sustainable development of the Nigerian forestry resources.

\section{Acknowledgements}

The researcher is grateful to the numerous local lumbers and the operators of the sawmills for their support.The contributions of Miss Taiwo Aderinoye in the collection of data is equally noted and fully appreciated.

\section{References}

Adekunle, M. F. (2005). Effective Wood utilization that ends to "zero wastes" in Ogun State. The Ogun Forestry Week Publication, 10-15.

Adekunle, V. A. J. (2005). Trends in Forest Reservation and Biodiversity conservation in Nigeria. In Okolo, E, Adekunle, V., \& Adeduntan, S. (eds). Environmental Sustainability and conservation in Nigeria.Environmental Conservation Research team (ECRT). Jubee-Niyi Publishers. pp. 82-89.

Adepoju, A. A., \& Salau, A. S. (2007). Economic Valuation of Non-Timber Forest Products (NTFPs). Munich Personal RePEc Archive (MPRA).

Adetula, T. (2002). Forest Resource Development in Nigeria,Ondo State:A case Study. in Abu J.E., P. I.Oni and L.Popoola (ed). Forestry and Challenges of Sustainable Livelihood,Proceedings of the $28^{\text {th }}$ Annual Conference of Forestry Association of Nigeria,held in Akure, Ondo State,Nov. $4^{\text {th }}-8^{\text {th }}, 2002$.

Aigner, D. J., Lovell, C. A. K., \& Schemidt, P. J. (1977). Formulation and estimation of stochastic frontier $\begin{array}{llllll}\text { production function models. Journal of Econometrics, } & 6, & \text { 21-37. }\end{array}$ http://dx.doi.org/10.1016/0304-4076(77)90052-5

Aiyeloja, A. A., \& Ajewole, O. I. (2006). Non-Timber Forest Products Marketing in Nigeria.A case study of Osun State. Educational Research and Reviews, 1(2), 52-58.

Ajakaiye, D. O. (2001). Socio-Economic Issues in National Development in Popoola. Proceedings of Association of Nigeria Conference. p. 56.

Andel, T. V. (2006). Non-Timber Forestry Products: The Value of Wild Plants. Agromisa Publication and CTA, The Netherlands.

Athanius, N. F. (2005). Production and Marketing of Non-Timber Forest Products (NTFPs): A major source of rural and national income in the South Western province of Cameroon.Paper presented at $17^{\text {th }}$ Commonwealth Forestry Conference 2005-Colombo, Sri-Lanka.

Awe, F., Osadebe, C. O., Imoagene, E., Fashina, A. Y., Eniola, T. S., \& Adeleke, E. O. (2011). Assessment of rural Households' objectives for gathering non-timber forest products (NTFPs) in Kogi State, Nigeria. 
Africa Journal of Environmental Science and Technology, 5(2), 143-148.

Battesse, G. E., \& Coelli, T. J. (1988). Prediction of firm level technical efficiencies with a generalized frontier $\begin{array}{lllll}\text { production functions and panel data Econometrics, 38, 389. } & \text { 38 }\end{array}$ http://dx.doi.org/10.1016/0304-4076(88)90053-X

Bravo-Ureta, B. E., \& Pinheiro, A. (1993). Efficiency analysis in developing country agriculture: a review of the frontier function literature. Agricultural Resource Economics Review, 2, 88-101.

Bravo-Ureta, B. E., \& Rieger, L. (1991). Dairy Farm Efficiency Measurement using stochastic frontiers and neo-classical duality. American Journal of Agricultural Economics, 73, 421-428. http://dx.doi.org/10.2307/1242726

FDF. (1984). Nigerian Forestry Statistics. Federal Department of Forestry, Lagos. pp. 34-36.

FDF. (2002). Federal Department Forestry, Abuja. Annual Report and Statement of account. pp. 17-23.

Hardin, G. (1968). The Tragedy of the Commons Science, 162(12), 43-48. Reprinted in Managing the Commons, (eds), G. Hardin and J. Baden, 16-30.

Meeusen, W., \& Van den Broeck, J., (1977). Efficiency estimation from Cobb-Douglas production functions with decomposed error. International Economic Review, 18, 435-444. http://dx.doi.org/10.2307/2525757

NPC. (2006). Census 2006. National Population Commission.

Ola-Adams, B. A. (1983). Effect of logging on Residual Stands of a Lowland Rainforest of Omo Forest Reserve, Nigeria. Paper presented at the $4^{\text {th }}$ annual Conference of science Association of Nigeria, University of Ibadan, ibadan.

Olumide, J. O. (2009). Ensuring Food Security Through Optimizing the Marketing of Non-Timber Forest Products in Oyo State, Nigeria. African Crop Science Conference Proceedings, 9, 773-776.

Ojo, A., \& Duze, M. (1977). Macmillan Senior School Atlas.Macmillan Nigeria Limited, pp. 6-7.

Pindyck, R. S., \& Rubinfeld, D. L. (1998). Econometric Models and Economic Forecasts. McGraw-Hill International Editions. (4th ed.). New York, pp. 298-329.

Sale, F. A. (2006). The Processing and Marketing of Non-Timber Forest Products (NTFPs) in Nigeria. In Popoola L. (ed.). proceedings of the $31^{\text {st }}$ Annual Conference of Forestry Association of Nigeria (FAN) held in Markurdi, Benue State, Nigeria, pp. 379-387.

Stonier, A. W., \& Hague, D. C. (1972). A textbook of Economic Theory (4th ed.). The English Language Book Society and Longman Group Limited, pp. 18-41. 